\title{
Rafsanjan AIDS clinic 1996-2005: problems faced and solutions found
}

N.Z. Shekholeslami' and M. Rezaeian ${ }^{2}$

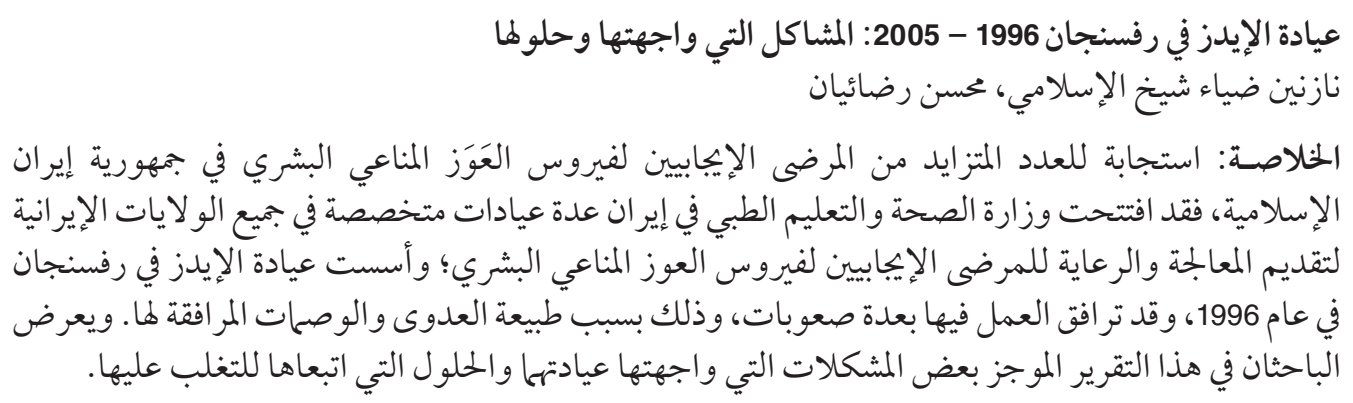

ABSTRACT In response to the growing number of the HIV-positive patients in the Islamic Republic of Iran, the Iranian Ministry of Health and Education established several special clinics in all Iranian provinces to provide treatment and care to HIV-positive patients. The Rafsanjan AIDS Clinic is one such clinic that was set up in 1996. Running such a clinic is not without difficulties, given the nature of the infection and the stigmas associated with it. In this brief report we discuss some of the problems faced at our clinic and the solutions found to overcome them.

\section{Centre anti-sida de Rafsanjan de 1996 à 2005 : problèmes rencontrés et solutions trouvées} RÉSUMÉ Afin de faire face au nombre croissant de personnes séropositives en République islamique d'Iran, le ministère iranien de la Santé et de l'Éducation a ouvert dans toutes les provinces du pays plusieurs centres spécialisés dispensant des traitements et des soins aux personnes séropositives. L'un de ces établissements, le centre anti-sida de Rafsanjan, a ainsi été créé en 1996. La gestion de ce type de centre n'est pas sans difficultés, compte tenu de la nature de l'infection et du caractère honteux qui lui est associé. Dans cette brève communication, nous évoquons certains des problèmes rencontrés par notre centre, ainsi que les solutions trouvées pour les surmonter. ${ }^{1}$ Department of Infectious Diseases; ${ }^{2}$ Department of Social Medicine, Rafsanjan Medical School, Rafsanjan,
Islamic Republic of Iran (Correspondence to N.Z. Shekholeslami: $n$ sheikholeslam@yahoo.com).

Received: 28/08/06; accepted: 14/02/07 


\section{Introduction}

Human immunodeficiency virus (HIV) infection has spread all over the world and in all continents. By the end of 2007, 33.2 million people were estimated to be living with HIV, 2.5 million became newly infected and 2.1 million developed AIDS [1]. The majority of new cases come from sub-Saharan Africa and Asia [1]. HIV is increasingly spreading in Asia [1] and the extent of this spread is very important because more than half the world's population lives on this continent.

The Islamic Republic of Iran has a population of about 70 million. The first HIV-positive patient, who had haemophilia, was documented in 1985 [2]. From the first recognition of HIV infection in the country until 2005, 13357 cases had been reported
[2]. Of this total number, 736 cases $(5 \%)$ subsequently developed AIDS. Table 1 shows the frequency distribution of HIVpositive and AIDS patients from 1985 to 2005 according to the route of transmission and age group and sex. As the table shows, the greatest proportion of the cases was in the 25-34 years age group and intravenousdrug abuse was the commonest route of transmission; $63.4 \%$ of the patients had been infected this way.

In response to the growing number of the HIV-positive patients, the Iranian Ministry of Health and Education established severed special clinics under the health care systems in all Iranian provinces. In each of these clinics, HIV-positive patients, who are usually referred from prisons, hospitals, laboratories and private clinics, are seen by a general physician. Usually,

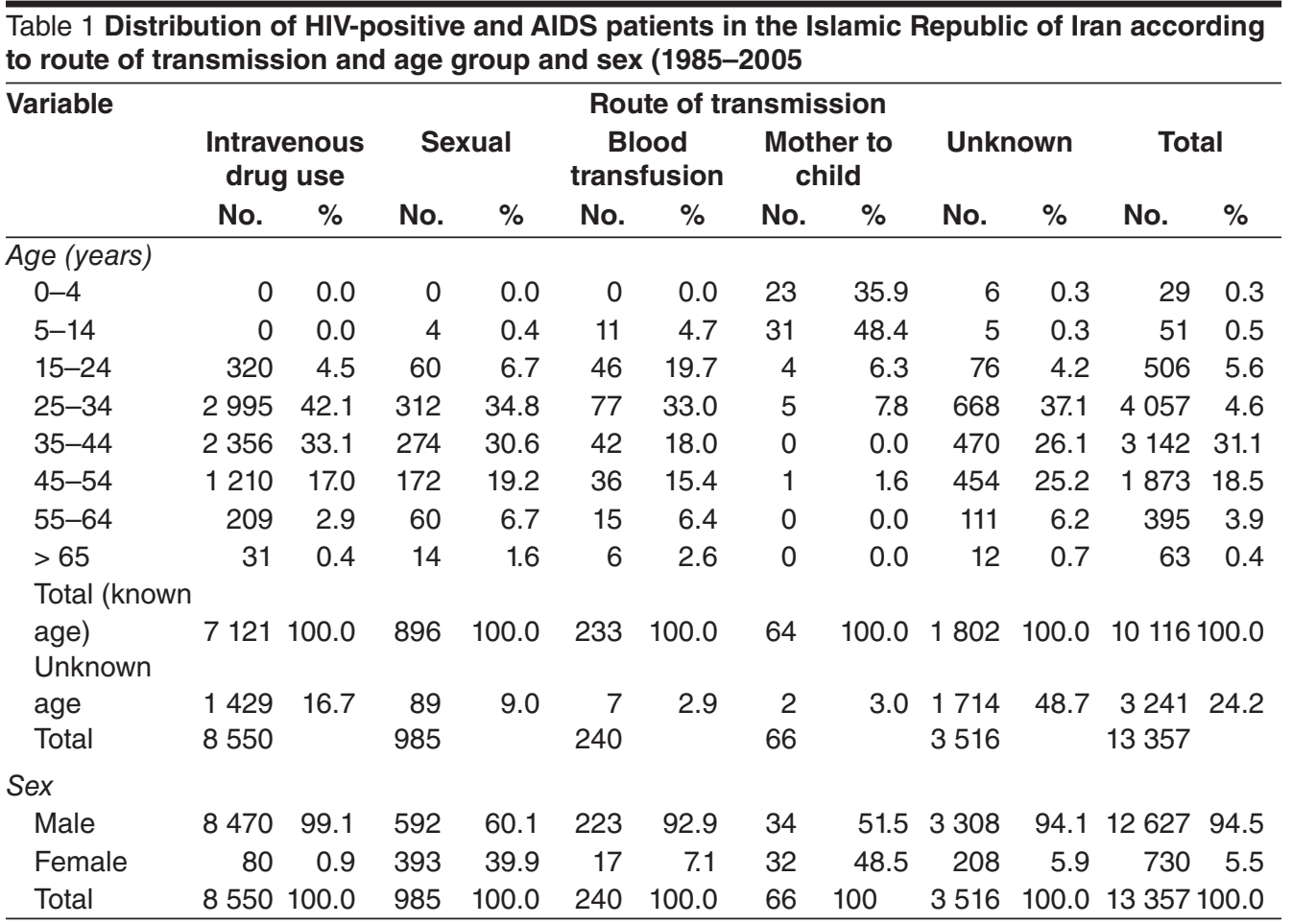

المجلة الصحية لشرق المتوسط، منظمة الصحة العالمية، المجلد الخامس عشر، العدد ع، 9 ب. 
other physicians, such as infectious diseases specialists, dermatologists, neurologists, psychiatrics, internists and dentists, collaborate with these clinics, as consultants. Financial and non-financial help is also offered to the patients and their relatives by the clinics and relevant nongovernmental organizations (NGOs). All the laboratory tests, drugs and hospitalization costs are covered by the clinic and are thus free of charge to the patient.

Since the care of HIV-infected individuals has an important role in the control of the AIDS epidemic, we describe here some of the problems faced by one such clinic, the Rafsanjan AIDS Clinic, and discuss the solutions found to overcome them. We hope that this communication will trigger more discussion on this important topic.

\section{History of the Rafsanjan AIDS clinic}

Rafsanjan is located in Kerman province (south-east of the Islamic Republic of Iran) and has a population of nearly 250000 . Rafsanjan AIDS Clinic was established in 1987. Up to 2005 this clinic had treated 57 HIV-positive patients. HIV infection was confirmed by Western blot [3]: 45 (78\%) patients were diagnosed by Rafsanjan prison authorities, $8(14 \%)$ by the Blood Transfusion Organization and $5(8 \%)$ directly by the AIDS clinic.

Table 2 shows some characteristics of the 57 patients treated at the clinic. The mean age of the patients was 34 years and the majority ( $89 \%$ ) were men. Of the men, $50(98 \%)$ were intravenous-drug abusers and $1(2 \%)$ was a haemophiliac and acquired the infection by blood transfusion. Among the women, $5(80 \%)$ had been infected by sexual contact with their husbands; for 1 patient $(20 \%)$ the route of infection was unknown. As regards marital status, 35\% were

\begin{tabular}{|c|c|c|}
\hline $\begin{array}{l}\text { Table } 2 \text { Characteristics of } \mathrm{HI} \\
\text { patients attending the Rafse } \\
(1987-2005)\end{array}$ & $\begin{array}{l}\text { IV-positive } \\
\text { anjan AID }\end{array}$ & elinic \\
\hline Variable & $\begin{array}{c}\text { No. } \\
(n=57)\end{array}$ & $\%$ \\
\hline Diagnosed by: & & \\
\hline Prison services & 44 & 77 \\
\hline Blood transfusion services & 8 & 14 \\
\hline AIDS clinic & 5 & 9 \\
\hline Sex & & \\
\hline Male & 51 & 89 \\
\hline Female & 6 & 11 \\
\hline Marital status & & \\
\hline Married & 20 & 35 \\
\hline Single & 20 & 35 \\
\hline Widowed & 6 & 11 \\
\hline Divorced & 8 & 14 \\
\hline Unknown & 3 & 5 \\
\hline Route of transmission & & \\
\hline Males $(n=51)$ & & \\
\hline Intravenous drug use & 50 & 98 \\
\hline Haemophilia & 1 & 2 \\
\hline Females $(n=6)$ & & \\
\hline $\begin{array}{l}\text { Sexual (acquired from } \\
\text { husband) }\end{array}$ & 5 & 83 \\
\hline Unknown & 1 & 17 \\
\hline Vaccination status & & \\
\hline Tetanus & 35 & 61 \\
\hline Influenza & 31 & 54 \\
\hline Hepatitis B & 25 & 44 \\
\hline
\end{tabular}

single, $35 \%$ were married, $14 \%$ divorced and $11 \%$ widowed. As regards vaccination status, $61 \%$ were vaccinated against tetanus, 54\% against influenza and 44\% against hepatitis B at the clinic. Among the married patients who agreed to further study (13 cases), none had an infected child. In all, 36 patients were studied further and 50\% of these had positive PPD (tuberculin) test and all had negative RPR (syphilis) test. Of 33 patients who were checked for hepatitis $\mathrm{C}$ virus antibodies and hepatitis B surface antigen, $88 \%$ were positive for hepatitis $\mathrm{C}$ and $19 \%$ for hepatitis B. 


\section{Problems faced at the Clinic and solutions found}

From the beginning, one of the most important problems faced by the staff of the Clinic was changing the negative attitude of healthcare personnel and the community to HIV-positive patients. We approached this by delivering educational programmes and pamphlets as widely as possible within schools, offices, factories, health centres, etc. We also strengthened our educational efforts by a series of radio programmes.

Since most of our patients were unable to work due to their illnesses or for social and cultural reasons, another problem the clinic faced was obtaining financial support for the patients and their families. At first we tried to approach NGOs and the wealthier members of the community. In this way we were initially able to provide money for the patients, but unfortunately we gradually realized that some of the patients spent the money on opium. Therefore, we began to provide them with vouchers rather than cash, which allowed them to buy clothes, food and other goods or services.

Furthermore, because most of the patients and their families had mental health problems, such as depression, and were in need of psychiatric counselling, we referred them to an experienced psychiatrist, who now sees the patients routinely. Similarly, providing dentistry services for the patients posed another important problem. In order to solve this we bought a dentistry unit for our clinic and for the last 4 years a part-time dentist has provided the necessary services to the patients in the clinic.

Since the highest risk group of patients were the intravenous-drug abusers in prison, we have focused more on the prison and tried to improve the situation of the prisoners. For instance, the most important problem in prison has been sharing infected syringes between prisoners. At the moment we are trying to deliver disposable syringes among HIV-infected and non-infected drug abusers within the prison environment. We are also conducting a routine screening programme for HIV and hepatitis B and C within the prison and also among healthy family members of the HIV-positive patients.

However, after release a number of the prisoners never refer to the clinic again and unfortunately their addresses are not always clear, therefore, our information about them remains incomplete, even though the risk which they pose to the community is obvious.

\section{References}

1. AIDS epidemic update. December 2007. Geneva, Joint United Nations Programme on HIV/AIDS and World Health Organization, 2007 (http://data.unaids.org/pub/ EPISlides/2007/2007_epiupdate_en.pdf, accessed 8 October 2008).

2. Akbari. M. [The epidemiologic study of HIV IAIDS in Iran]. Tehran, Ministry of Health and Medical, Education, 2005:34-5 [in Farsi].

3. Centers for Disease Control and Prevention. Revised guidelines for HIV counselling, testing and referral. Morbidity and mortality weekly report. Recommendations and reports, 2001, 50(RR-19):1-57. 